\title{
ANALISIS DISTRIBUSI DAN POLA KEPENGARANGAN ARTIKEL PADA JURNAL RISET GEOLOGI DAN PERTAMBANGAN TAHUN 2009-2018
}

\author{
Didik Prata Wijaya ${ }^{1^{*}}$; Abdurrakhman Prasetyadi ${ }^{{ }^{*}}$ \\ Pusat Data dan Dokumentasi Ilmiah (Lembaga Ilmu Pengetahuan Indonesia) \\ Korespondensi: di2kwijaya@gmail.com¹,abdurrakhmanpras@gmail.com²
}

\begin{abstract}
ABSTRAK
Tulisan ini membahas tentang kajian analisis distribusi dan pola kepengarangan artikel pada jurnal riset geologi dan pertambangan tahun 2009-2018. Tujuan kajian ini adalah untuk mengetahui distribusi artikel berdasarkan tahun, distribusi artikel berdasarkan nomor terbitan, kolaborasi (pola kepengarangan) dan tingkat kolaborasi, panjang artikel yang diterbitkan, distribusi sitasi, serta untuk mengetahui rerata penulis perartikel. Data penelitian ini didapatkan dari artikel jurnal riset geologi dan pertambangan yang terbit pada tahun 2009-2018. Data dari artikel tersebut dianalisis secara deskriptif yang diolah dengan menggunakan bantuan Microsoft Excel untuk memudahkan pendistribusian data dan tampilan dalam format tabel. Selanjutnya pengolahan data tersebut digunakan untuk menentukan kategori artikel berdasarkan tahun, artikel berdasarkan nomor terbitan, kolaborasi (pola kepengarangan) dan tingkat kolaborasi, panjang artikel yang diterbitkan, rerata penulis perartikel, serta distribusi sitasi. Hasil dari kajian ini dapat disimpulkan bahwa distribusi artikel pada Jurnal Riset Geologi dan Pertambangan selama tahun 2009-2018 adalah sebanyak 135 artikel dengan jumlah artikel tertinggi ada pada tahun 2017 dan 2018 yang memuat 20 artikel (14.81\%) dan yang terendah pada tahun 2009 yaitu sebanyak 11 artikel (8,15\%). Pola kepengarangan selama tahun 2009-2018 menunjukkan bahwa hasil penelitian yang dilakukan secara individual lebih sedikit dibandingkan yang dilakukan secara berkolaborasi yaitu sebesar 0.6 . Penulis terbanyak adalah pada periode tahun 2017 yaitu sebanyak 67 penulis $(18.82 \%)$ sedangkan yang terendah adalah pada periode tahun 2012 dan 2013 yaitu sebanyak 24 penulis $(6.74 \%)$. Sedangkan rerata penulis perartikel tertinggi adalah periode tahun 2014 yaitu 3.50 penulis perartikel dan yang terendah adalah periode tahun 2012 dan 2013 yaitu 2.00 penulis perartikel. Jumlah artikel terbanyak berada pada jumlah halaman $11-15$ yaitu 66 judul $(48,89 \%)$ dan yang terendah adalah artikel dengan jumlah halaman 1-5 dan 16-20 yaitu 5 judul (3.70\%). Artikel terbanyak disitir ada pada tahun 2018 yaitu sebanyak 107 sitiran (34.52\%), Sedangkan jumlah sitasi terendah adalah pada periode tahun 2011 dengan jumlah sitasi sebanyak $2(0.65 \%)$.
\end{abstract}

Kata kunci: Bibliometrika; Pola Kepengarangan; Analisis Sitasi.

\section{PENDAHULUAN}

Pusat Penelitian Geoteknologi adalah salah satu satuan kerja di bawah Kedeputian Ilmu Pengetahuan Kebumian LIPI yang didirikan pada tanggal 1 Agustus 1963. Visi dari Pusat Penelitian Geoteknologi LIPI adalah menjadi institusi riset terpercaya yang berperan dalam memberikan solusi permasalahan di bidang Geoteknologi. Visi tersebut dimaknai sebagai berikut: Pusat Penelitian Geoteknologi LIPI, adalah instansi pemerintah yang tugas dan fungsinya melakukan tugas pemerintahan di bidang penelitian ilmu pengetahuan di 
bidang geoteknologi. Berkelas dunia, dimaksudkan Pusat Penelitian Geoteknologi LIPI mendapat pengakuan Internasional yang mencerminkan kedaulatan dalam bidang ilmu pengetahuan di bidang geoteknologi. Penelitian, merupakan kegiatan pengumpulan, pengolahan, analisis, dan penyajian data yang dilakukan secara sistematis dan objektf untuk memecahkan suatu persoalan atau menguji hipotesis. Pengembangan ilmu pengetahuan di bidang geoteknologi, merupakan kegiatan pengembangan hasil penelitian sehingga diperoleh teori baru dan invensi yang mendukung pemanfaatan ilmu pengetahuan oleh stakeholder. Pemanfaatan ilmu pengetahuan di bidang geoteknologi, dimaksudkan bahwa hasil-hasil penelitian LIPI dimanfaatkan oleh stakeholder untuk kemandirian bangsa. Daya saing bangsa, dimaksudkan sebagai kemampuan/kapasitas bangsa dalam hubungan antar negara berbasis pada hasil penelitian, pengembangan dan pemanfaatan ilmu pengetahuan di bidang geoteknologi.

Salah satu makna dari visi Pusat Penelitian Geoteknologi tersebut adalah hasil-hasil penelitian di bidang geoteknologi dapat dimanfaatkan oleh stakeholder. Tentunya membutuhkan suatu media untuk mempermudah dalam penyebarluasan informasi hasilhasil penelitian tersebut. Jurnal Riset Geologi dan Pertambangan menjadi salah satu media untuk penyebarluasan informasi hasil-hasil penelitian.

Jurnal Riset Geologi dan Pertambangan adalah jurnal ilmiah peer-review yang didirikan pada tahun 1977, yang meliputi Geologi, Pertambangan, Geofisika Terapan dan Topik Terkait Lainnya. Jurnal ini telah terakreditasi (Sinta 2) selama lima tahun berdasarkan Surat Keputusan Direktorat Jenderal Penelitian dan Pengembangan, Kementerian Riset, Teknologi, dan Pendidikan Tinggi Republik Indonesia No. 3 / E / KPT / 2019, yang berlaku untuk volume 28 - 33. Jurnal ini disarikan dan diindeks dalam Indonesia Journal Database (ISJD), Science and Technology Index (Sinta), Google Scholar, Crossref, Directory of Open Access Journal (DOAJ) dan Open Academic Journal Index (OAJI).

Berdasarkan peraturan Menteri Riset, Teknologi, dan Pendidikan Tinggi Republik Indonesia Nomor 9 Tahun 2018 Tentang Akreditasi Jurnal Ilmiah, jurnal ilmiah adalah bentuk pemberitaan atau komunikasi yang memuat karya ilmiah dan diterbitkan berjadwal dalam bentuk elektronik dan/atau tercetak. Jurnal Ilmiah dapat diterbitkan oleh perguruan tinggi, organisasi profesi, kementerian, lembaga pemerintah nonkementerian, lembaga penelitian dan pengembangan, Lembaga pendidikan, perusahaan penerbitan, dan/atau badan usaha; dan/atau berafiliasi dengan perguruan tinggi, organisasi profesi, kementerian, lembaga pemerintah nonkementerian, lembaga penelitian dan pengembangan, Lembaga pendidikan, dan/atau badan usaha. Jurnal ilmiah berfungsi meregistrasi kegiatan 
Bibliotech : Jurnal Ilmu Perpustakaan dan Informasi, 4 (1) 2019

kecendekiaan, mengarsipkan temuan hasil kegiatan kecendekiaan, ilmuan, mengakui hasil kegiatan yang memenuhi persyaratan ilmiah, mendiseminasikan hasil kegiatan kecendekiaan, mendiseminasikan hasil pengabdian kepada masyarakat, dan melindungi hasil karya peneliti/cendekiawan.

Bibliometrik adalah evaluasi kuantitatif dari pola publikasi. Studi kuantitatif sebagaimana tercermin dalam bibliografi. Analisis bibliometrik publikasi ilmiah merupakan aspek penting dari penelitian dalam bidang ilmu informasi. Studi bibliometrik digunakan untuk mengidentifikasi pola publikasi, kepenulisan, kutipan, liputan jurnal sekunder, dan seterusnya. Faktor-faktor ini dapat memberikan wawasan tentang dinamika subjek, yang berdampak pada penanganan dan pengelolaan informasi yang lebih baik. Analisis bibliometrik telah mendapat perhatian yang cukup dan telah banyak diterapkan untuk mengevaluasi kinerja penelitian para ilmuwan dan pertumbuhan berbagai disiplin ilmu. Lebih lanjut dapat dicatat bahwa data bibliometrik dapat digunakan dalam identifikasi bidang penelitian yang muncul, dan dalam evaluasi kinerja penelitian dari masing-masing ilmuwan, kelompok penelitian dan negara yang bertujuan untuk mengintegrasikan struktur kognitif atau intelektual penelitian dengan maksud untuk menilai hubungan antara penulis, lembaga, artikel jurnal dan sebagai sarana untuk membantu prosedur peer review (Tupan \& Rahayu, R.N., 2018).

Meskipun kajian mengenai distribusi dan pola kepengarangan telah banyak dilakukan oleh peneliti sebelumnya, namun kajian terhadap jurnal riset geologi dan pertambangan ini belum pernah dilakukan. Penelitian ini diharapkan dapat menjawab pertanyaan sebagai berikut:

1) Bagaimanakah distribusi artikel berdasarkan tahun dari Jurnal Riset Geologi dan Pertambangan?

2) Bagaimanakah distribusi artikel berdasarkan nomor terbitan dari Jurnal Riset Geologi dan Pertambangan?

3) Bagaimana tingkat kolaborasi pengarang pada Jurnal Riset Geologi dan Pertambangan?

4) Bagaimana jumlah halaman artikel yang diterbitkan oleh Jurnal Riset Geologi dan Pertambangan?

5) Bagaimana distribusi sitasi pada Jurnal Riset Geologi dan Pertambangan?

6) Bagaimana rata rata penulis per- artikel pada Jurnal Riset Geologi dan Pertambangan? 
Bibliotech : Jurnal Ilmu Perpustakaan dan Informasi, 4 (1) 2019

Tujuan dari kajian ini adalah untuk mengetahui distribusi artikel berdasarkan tahun, untuk mengetahui distribusi artikel berdasarkan nomor terbitan, untuk mengetahui kolaborasi (pola kepengarangan) dan tingkat kolaborasi, untuk mengetahui panjang artikel yang diterbitkan, untuk mengetahui distribusi sitasi, serta untuk mengetahui rerata penulis perartikel

Hasil dari penelitian ini diharapkan dapat memberikan masukan kepada Pusat Penelitian Geoteknologi mengenai distribusi dan pola kepengarangan artikel pada jurnal riset geologi dan pertambangan. Sehingga dapat dijadikan bahan pertimbangan dalam menetapkan kebijakan untuk meningkatkan mutu atau kualitas jurnal riset geologi dan pertambangan ini. Selain itu diharapkan dengan penelitian ini dapat dijadikan sebagai rujukan atau tambahan literatur bagi yang akan melakukan penelitian, terutama dalam objek kajian yang sama, tetapi dalam konteks yang berbeda.

\section{METODE}

Penelitian ini dilakukan terhadap Jurnal Riset Geologi dan Pertambangan yang terbit tahun 2009-2018 (terbitan selama sepuluh tahun). Dengan perincian: volume 19 nomor $1 \&$ 2 tahun 2009, volume 20 nomor $1 \& 2$ tahun 2010, volume 21 nomor $1 \& 2$ tahun 2011, volume 22 nomor $1 \& 2$ tahun 2012, volume 23 nomor $1 \& 2$ tahun 2013, volume 24 nomor $1 \& 2$ tahun 2014, volume 25 nomor $1 \& 2$ tahun 2015, volume 26 nomor $1 \& 2$ tahun 2016, volume 27 nomor $1 \& 2$ tahun 2017, dan volume 28 nomor $1 \& 2$ tahun 2018.

Data artikel Jurnal Riset Geologi dan Pertambangan diunduh secara online melalui alamat https://jrisetgeotam.com/index.php/jrisgeotam/index. Data dari artikel tersebut dianalisis secara deskriptif yang diolah dengan menggunakan bantuan Microsoft Excel untuk memudahkan pendistribusian data dan tampilan dalam format tabel. Selanjutnya pengolahan data tersebut digunakan untuk menentukan kategori artikel berdasarkan tahun, artikel berdasarkan nomor terbitan, kolaborasi (pola kepengarangan) dan tingkat kolaborasi, panjang artikel yang diterbitkan, rerata penulis perartikel, serta distribusi sitasi.

Untuk menghitung tingkat kolaborasi penulis digunakan rumus Subramanyam sebagai berikut:

$$
C=\frac{N m}{(N m+N s)}
$$

Di mana:

$\mathrm{C}=$ tingkat kolaborasi peneliti suatu disiplin ilmu, dengan nilai berada pada interval 0 sampai dengan 1 , atau $[0,1]$ 
Bibliotech : Jurnal Ilmu Perpustakaan dan Informasi, 4 (1) 2019

$\mathrm{Nm}=$ total hasil penelitian dari peneliti suatu disiplin ilmu pada tahun tertentu yang dilakukan secara berkolaborasi

$\mathrm{Ns}=$ total hasil penelitian dari peneliti suatu disiplin ilmu pada tahun tertentu yang dilakukan secara individual

- Apabila nilai $\mathrm{C}=0$ maka hasil penelitian pada suatu bidang seluruhnya dilakukan secara individual (peneliti tunggal).

- Apabila nilai $\mathrm{C}$ lebih besar dari nol dan kurang dari setengah $(0<\mathrm{C}<0,5)$ maka hasil penelitian yang dilakukan secara individual lebih besar dibandingkan dengan yang dilakukan secara berkolaborasi.

- Apabila nilai $\mathrm{C}=0,5$ maka penelitian yang dilakukan secara individual sama banyaknya dengan yang dilakukan secara berkolaborasi.

- Apabila nilai $\mathrm{C}$ lebih besar dari 0,5 dan kurang dari $1(0,5<\mathrm{C}<1)$ maka hasil penelitian yang dilakukan secara individual lebih sedikit dibandingkan yang dilakukan secara berkolaborasi.

- Apabila nilai $\mathrm{C}=1$ maka penelitian pada suatu bidang seluruhnya dilakukan secara berkolaborasi (Savitri, 2018).

Untuk analisis sitasi Jurnal Riset Geologi dan Pertambangan yang terbit tahun 20092018 dilakukan dengan menggunakan google scholar dan Sinta (Science and Technology Index).

\section{HASIL DAN PEMBAHASAN}

\subsection{Distribusi Artikel Berdasarkan Tahun}

Tabel 1. Distribusi artikel berdasarkan tahun

\begin{tabular}{|c|c|c|c|c|}
\hline Periode & $\begin{array}{c}\text { Volume } \\
\text { Jurnal }\end{array}$ & $\begin{array}{c}\text { Jumlah } \\
\text { Terbitan } \\
\text { Pertahun }\end{array}$ & $\begin{array}{c}\text { Jumlah } \\
\text { Artikel Yang } \\
\text { Dimuat }\end{array}$ & $\begin{array}{c}\text { Persentase } \\
\mathbf{( \% )}\end{array}$ \\
\hline 2018 & 28 & 2 & 20 & 14.81 \\
\hline 2017 & 27 & 2 & 20 & 14.81 \\
\hline 2016 & 26 & 2 & 12 & 8.89 \\
\hline 2015 & 25 & 2 & 12 & 8.89 \\
\hline 2014 & 24 & 2 & 12 & 8.89 \\
\hline 2013 & 23 & 2 & 12 & 8.89 \\
\hline 2012 & 22 & 2 & 12 & 8.89 \\
\hline 2011 & 21 & 2 & 12 & 8.89 \\
\hline 2010 & 20 & 2 & 12 & 8.89 \\
\hline 2009 & 19 & 2 & 11 & 8.15 \\
\hline \multicolumn{7}{|c|}{ Jumlah } & $\mathbf{1 3 5}$ & $\mathbf{1 0 0}$ \\
\hline
\end{tabular}


Bibliotech : Jurnal Ilmu Perpustakaan dan Informasi, 4 (1) 2019

Dari tabel 1 dapat diketahui bahwa selama tahun 2009 sampai dengan tahun 2018 terdapat 10 volume dan setiap volume menerbitkan 2 nomor. Sedangkan jumlah artikel yang dimuat di dalam Jurnal Riset Geologi dan Pertambangan sebanyak 135 judul. Dengan demikian artikel terbanyak diterbitkan jurnal Riset Geologi dan Pertambangan adalah Tahun 2017 volume 27 dan Tahun 2018 volume 28 yaitu sebanyak 20 judul (14.81\%). Serta yang terendah pada Tahun 2009 volume 19, yaitu sebanyak 11 judul (8.15\%)

\subsection{Distribusi Artikel Berdasarkan Nomor Terbitan}

Tabel 2. Distribusi artikel berdasarkan nomor terbitan

\begin{tabular}{|c|c|c|c|c|}
\hline \multirow{2}{*}{$\begin{array}{c}\text { Volume } \\
\text { Jurnal }\end{array}$} & \multicolumn{2}{|c|}{ Nomor Jurnal } & \multirow{2}{*}{$\begin{array}{c}\text { Jumlah } \\
\text { Artikel }\end{array}$} & $\begin{array}{c}\text { Persentase } \\
(\%)\end{array}$ \\
\cline { 2 - 3 } & $\mathbf{1}$ & $\mathbf{2}$ & 20 & 14.81 \\
\hline 28 & 10 & 10 & 20 & 14.81 \\
\hline 27 & 10 & 10 & 12 & 8.89 \\
\hline 26 & 6 & 6 & 12 & 8.89 \\
\hline 25 & 6 & 6 & 12 & 8.89 \\
\hline 24 & 6 & 6 & 12 & 8.89 \\
\hline 23 & 6 & 6 & 12 & 8.89 \\
\hline 22 & 6 & 6 & 12 & 8.89 \\
\hline 21 & 6 & 6 & 12 & 8.89 \\
\hline 20 & 6 & 6 & 11 & 8.15 \\
\hline 19 & 5 & 6 & $\mathbf{1 3 5}$ & $\mathbf{1 0 0}$ \\
\hline
\end{tabular}

Dari tabel 2 dapat diketahui bahwa artikel Jurnal Riset Geologi dan Pertambangan yang tertinggi di terbitkan adalah pada volume 27 nomor 1 dan 2 serta volume 28 nomor 1 dan 2, dengan masing-masing nomor menerbitkan 10 artikel. Sedangkan yang terendah adalah volume 19 nomor 1 yaitu dengan menerbitkan sebanyak 5 artikel.

\subsection{Jumlah Pengarang Tunggal Dan Kolaborasi Per Artikel}

Tabel 3. Jumlah pengarang tunggal dan kolaborasi per artikel

\begin{tabular}{|c|c|c|c|}
\hline \multirow{2}{*}{ Periode } & \multicolumn{2}{|c|}{ Kepengarangan } & \multirow{2}{*}{ Jumlah Artikel } \\
\cline { 2 - 3 } & Tunggal & Kolaborasi & 20 \\
\hline 2018 & 4 & 16 & 20 \\
\hline 2017 & 3 & 17 & 12 \\
\hline 2016 & 4 & 8 & 12 \\
\hline 2015 & 6 & 6 & 12 \\
\hline 2014 & 2 & 10 & 12 \\
\hline 2013 & 5 & 7 & \\
\hline
\end{tabular}


Bibliotech : Jurnal Ilmu Perpustakaan dan Informasi, 4 (1) 2019

\begin{tabular}{|c|c|c|c|}
\hline 2012 & 7 & 5 & 12 \\
\hline 2011 & 4 & 8 & 12 \\
\hline 2010 & 2 & 10 & 12 \\
\hline 2009 & 5 & 6 & 11 \\
\hline Total & $\mathbf{4 2}$ & $\mathbf{9 3}$ & $\mathbf{1 3 5}$ \\
\hline Persentase (\%) & 31.11 & 68.89 & 100 \\
\hline
\end{tabular}

Dari tabel 3 dapat diketahui bahwa artikel terbanyak ditulis oleh pengarang secara kolaborasi yaitu sebanyak 93 artikel (68.89\%) dan sisanya 42 (31.11\%) artikel dilakukan oleh pengarang tunggal. Dari kepengarangan kolaborasi tertinggi pada periode tahun 2017 yaitu sebanyak 17 artikel dan terendah pada periode tahun 2012 yaitu sebanyak 5 artikel. Sedangkan kepengarangan tunggal tertinggi pada periode tahun 2012 yaitu 7 artikel dan terendah pada periode tahun 2010 dan 2014 yaitu sebanyak 2 artikel. Perhitungan tingkat kolaborasi pengarang dilakukan dengan menggunakan rumus Subramanyam, yaitu: $\mathrm{C}=$ $\mathrm{Nm} /(\mathrm{Nm}+\mathrm{Ns})$. Jadi $93 /(93+42)=0.6$, sehingga nilai $\mathrm{C}$ adalah 0.6 . Apabila nilai $\mathrm{C}$ lebih besar dari 0,5 dan kurang dari $1(0,5<\mathrm{C}<1)$ maka hasil penelitian yang dilakukan secara individual lebih sedikit dibandingkan yang dilakukan secara berkolaborasi.

Tabel 4. Distribusi pengarang per tahun dan jumlah pengarang dalam artikel

\begin{tabular}{|c|c|c|c|c|c|c|c|c|c|c|}
\hline $\begin{array}{c}\text { Jumlah } \\
\text { pengarang } \\
\text { perartikel }\end{array}$ & 2009 & 2010 & 2011 & 2012 & 2013 & 2014 & 2015 & 2016 & 2017 & 2018 \\
\hline 1 & 5 & 2 & 4 & 7 & 5 & 2 & 6 & 4 & 3 & 4 \\
\hline 2 & 3 & 5 & 2 & 2 & 3 & 2 & 1 & & 4 & 3 \\
\hline 3 & 1 & 4 & 3 & 1 & 3 & 4 & 3 & 7 & 4 & 7 \\
\hline 4 & - & - & 1 & 1 & 1 & - & 2 & - & 5 & 4 \\
\hline 5 & 1 & 1 & - & 1 & - & 1 & - & - & 2 & 2 \\
\hline 6 & - & - & 1 & - & - & 2 & - & - & 1 & - \\
\hline 7 & 1 & - & - & - & - & 1 & - & 1 & - & - \\
\hline 8 & - & - & 1 & - & - & - & - & - & 1 & - \\
\hline 9 & - & - & - & - & - & - & - & - & - & - \\
\hline 10 & - & - & - & - & - & - & - & - & - & - \\
\hline Total & 11 & 12 & 12 & 12 & 12 & 12 & 12 & 12 & 20 & 20 \\
\hline
\end{tabular}

Menghitung koefisien kolaborasi per tahun dapat menggunakan rumus MCC (Modified Collaborative Coefficient) dari Savanur \& Srikanth (2009) untuk meningkatkan kinerja perhitungan kolaborasi. Dengan rincian $\mathrm{K}$ menjadi artikel penelitian yang diterbitkan dalam disiplin atau dalam jurnal selama periode tertentu.

$\mathrm{fj}=$ jumlah artikel yang memiliki $\mathrm{j}$ penulis dalam koleksi $\mathrm{K}$; 
Bibliotech : Jurnal Ilmu Perpustakaan dan Informasi, 4 (1) 2019

$\mathrm{N}=$ jumlah total artikel dalam $\mathrm{K} . \mathrm{N}=\mathrm{Pj}$ fj; dan

$\mathrm{A}=$ jumlah total penulis dalam koleksi $\mathrm{K}$.

Berikut nilai MCC pada tahun 2017 yang telah dihitung:

$$
\begin{aligned}
& \mathrm{K}=\frac{A}{A-1}\left\{1-\frac{\Sigma_{j}^{A}=1(1 / j) f i}{N}\right\} \\
= & \left(\frac{20}{20-1}\right)\left(1-\left\{\frac{(1 \times 3)+(1 / 2 \times 4)+(1 / 3 \times 4)+(1 / 4 \times 5)+(1 / 5 \times 2)+(1 / 6 \times 1)+(1 / 8 \times 1)}{20}\right\}\right) \\
= & 1.0009\left(1-\frac{3+2+1.333+1.25+0.4+0.166+0.125}{20}\right) \\
= & 1.0009(1-8.274 / 20) \\
= & 1.0009(1-0.4137) \\
= & 1.0009 \times 0.5863 \\
= & 0.5868
\end{aligned}
$$

Demikian pula dengan nilai MCC tahun 2009, 2010, 2011, 2012, 2013, 2014, 2015, 2016, dan 2018 dapat dilihat pada Grafik 1.

\section{Grafik 1. Hasil perhitungan nilai MCC (Modified Collaborative Coefficient)}

\section{Nilai MCC per Tahun}

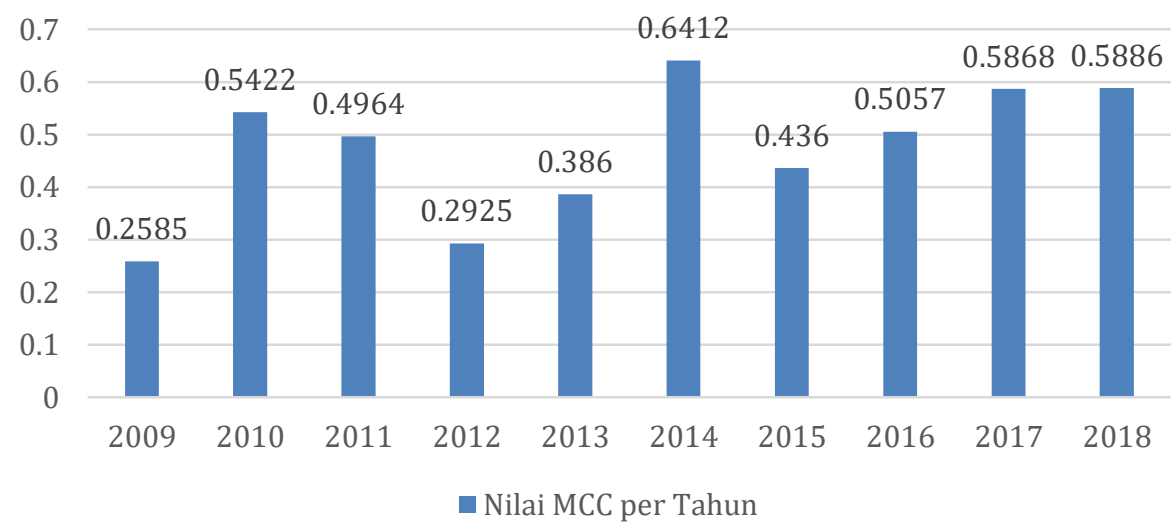

\subsection{Rerata Indeks Penulis Per Artikel}

Tabel 5. Rerata indeks penulis per artikel

\begin{tabular}{|c|c|c|c|c|c|}
\hline Periode & Vol Jurnal & $\begin{array}{c}\text { Jumlah } \\
\text { Artikel } \\
\text { yang } \\
\text { dimuat }\end{array}$ & $\begin{array}{c}\text { Jumlah } \\
\text { Penulis }\end{array}$ & Persentase & $\begin{array}{c}\text { Rerata } \\
\text { penulis/artikel }\end{array}$ \\
\hline 2018 & 28 & 20 & 57 & 16.01 & 2.85 \\
\hline 2017 & 27 & 20 & 67 & 18.82 & 3.35 \\
\hline 2016 & 26 & 12 & 32 & 8.99 & 2.67 \\
\hline 2015 & 25 & 12 & 25 & 7.02 & 2.08 \\
\hline 2014 & 24 & 12 & 42 & 11.80 & 3.50 \\
\hline 2013 & 23 & 12 & 24 & 6.74 & 2.00 \\
\hline 2012 & 22 & 12 & 24 & 6.74 & 2.00 \\
\hline
\end{tabular}


Bibliotech : Jurnal Ilmu Perpustakaan dan Informasi, 4 (1) 2019

\begin{tabular}{|l|c|c|c|c|c|}
\hline 2011 & 21 & 12 & 30 & 8.43 & 2.50 \\
\hline 2010 & 20 & 12 & 29 & 8.15 & 2.42 \\
\hline 2009 & 19 & 11 & 26 & 7.30 & 2.36 \\
\hline & & 135 & 356 & 100 & 2.39 \\
\hline
\end{tabular}

Dari tabel 6 dapat diketahui bahwa penulis terbanyak adalah pada periode tahun 2017 yaitu sebanyak 67 penulis $(18.82 \%)$ sedangkan yang terendah adalah pada periode tahun 2012 dan 2013 yaitu sebanyak 24 penulis (6.74\%). Sedangkan rerata penulis perartikel tertinggi adalah periode tahun 2014 yaitu 3.50 penulis perartikel dan yang terendah adalah periode tahun 2012 dan 2013 yaitu 2.00 penulis perartikel.

\subsection{Distribusi Jumlah Halaman Perartikel}

Tabel 6. Panjang artikel yang dimuat dalam jurnal

\begin{tabular}{|c|c|c|c|c|c|}
\hline \multirow[t]{2}{*}{ Periode } & \multicolumn{4}{|c|}{ Panjang (halaman) } & \multirow{2}{*}{$\begin{array}{l}\text { Jumlah } \\
\text { Artikel }\end{array}$} \\
\hline & $1-5$ & 6-10 & 11-15 & $16-20$ & \\
\hline 2018 & 0 & 8 & 11 & 1 & 20 \\
\hline 2017 & 1 & 13 & 5 & 1 & 20 \\
\hline 2016 & 0 & 4 & 7 & 1 & 12 \\
\hline 2015 & 2 & 7 & 3 & 0 & 12 \\
\hline 2014 & 0 & 3 & 7 & 2 & 12 \\
\hline 2013 & 0 & 3 & 9 & 0 & 12 \\
\hline 2012 & 0 & 7 & 5 & 0 & 12 \\
\hline 2011 & 2 & 3 & 7 & 0 & 12 \\
\hline 2010 & 0 & 6 & 6 & 0 & 12 \\
\hline 2009 & 0 & 5 & 6 & 0 & 11 \\
\hline Total & 5 & 59 & 66 & 5 & 135 \\
\hline Persentase & 3.70 & 43.70 & 48.89 & 3.70 & 100 \\
\hline
\end{tabular}

Dari tabel 6 dapat diketahui panjang halaman artikel terbanyak yang dimuat dalam jurnal adalah 11-15 halaman dengan 66 artikel (48.89\%). Sedangkan yang terendah adalah 15 halaman dan 16-20 halaman dengan 5 artikel (3.70\%).

\subsection{Periode Distribusi Sitasi}

Tabel 7. Periode Distribusi Sitasi

\begin{tabular}{|c|c|r|}
\hline Periode & Jumlah Sitasi & Persentase \\
\hline 2018 & 107 & 34.52 \\
\hline 2017 & 83 & 26.77 \\
\hline 2016 & 33 & 10.65 \\
\hline 2015 & 31 & 10.00 \\
\hline 2014 & 18 & 5.81 \\
\hline 2013 & 14 & 4.52 \\
\hline 2012 & 14 & 4.52 \\
\hline 2011 & 2 & 0.65 \\
\hline 2010 & 5 & 1.61 \\
\hline 2009 & 3 & 0.97 \\
\hline
\end{tabular}


Bibliotech : Jurnal Ilmu Perpustakaan dan Informasi, 4 (1) 2019

Berdasarkan hasil penelusuran sitasi Jurnal Riset Geologi dan Pertambangan melalui google scholar dan Sinta (Science and Technology Index) seperti ditampilkan pada tabel 8 menunjukkan bahwa jumlah sitasi tertinggi adalah pada periode tahun 2018 dengan jumlah sitasi sebanyak 107 (34.52\%). Sedangkan jumlah sitasi terendah adalah pada periode tahun 2011 dengan jumlah sitasi sebanyak 2 (0.65\%).

\section{KESIMPULAN}

Berdasarkan hasil analisis dan pembahasan dapat disimpulkan bahwa distribusi artikel pada Jurnal Riset Geologi dan Pertambangan selama tahun 2009-2018 adalah sebanyak 135 artikel dengan jumlah artikel tertinggi ada pada tahun 2017 dan 2018 yang memuat 20 artikel (14.81\%) dan yang terendah berada pada tahun 2009 yaitu sebanyak 11 artikel (8,15\%). Pola kepengarangan selama tahun 2009-2018 menunjukkan bahwa hasil penelitian yang dilakukan secara individual lebih sedikit dibandingkan yang dilakukan secara berkolaborasi yaitu sebesar 0.6. Penulis terbanyak adalah pada periode tahun 2017 yaitu sebanyak 67 penulis (18.82\%) sedangkan yang terendah adalah pada periode tahun 2012 dan 2013 yaitu sebanyak 24 penulis (6.74\%). Sedangkan rerata penulis perartikel tertinggi adalah periode tahun 2014 yaitu 3.50 penulis perartikel dan yang terendah adalah periode tahun 2012 dan 2013 yaitu 2.00 penulis perartikel. Jumlah artikel terbanyak berada pada jumlah halaman 11-15 yaitu 66 judul (48,89\%) dan yang terendah adalah artikel dengan jumlah halaman 1-5 dan 16-20 yaitu 5 judul (3.70\%). Artikel terbanyak disitir ada pada tahun 2018 yaitu sebanyak 107 sitiran (34.52\%), Sedangkan jumlah sitasi terendah adalah pada periode tahun 2011 dengan jumlah sitasi sebanyak $2(0.65 \%)$.

\section{DAFTAR PUSTAKA}

Google Cendekia. https://scholar.google.com/citations?user=86dvEz4AAAAJ\&hl=en, diakses tanggal 22 Juli 2019.

Jurnal Riset Geologi dan Pertambangan (2019) Pusat Penelitian Geoteknologi LIPI, Bandung, https://jrisetgeotam.com/index.php/jrisgeotam, diakses tanggal 17 Juli 2019.

Menteri Riset, Teknologi, dan Pendidikan Tinggi Republik Indonesia. 2018. Peraturan Menteri Riset, Teknologi, Dan Pendidikan Tinggi Republik Indonesia Nomor 9 Tahun 2018 Tentang Akreditasi Jurnal Ilmiah, https://risbang.ristekdikti.go.id/wpcontent/uploads/2019/07/Salinan-Permenristekdikti-Nomor-9-Tahun-2018.pdf, diakses tanggal 29 Juli 2019. 
Bibliotech : Jurnal Ilmu Perpustakaan dan Informasi, 4 (1) 2019

Savitri, S. (2018). Kajian Bibliometrik Terhadap Karakteristik Kepengarangan Dan Artikel Pada Buletin Pertanian Perkotaan. Jurnal Perpustakaan Pertanian. 27(1), 23-29.

Savanur, K. Srikanth, R. (2010). Modified Collaborative Coefficient: A New Measure for Quantifying The Degree Of Research Collaboration. Scientometrics. 84(2), pp 365371. DOI: DOI 10.1007/s11192-009-0100-4.

Sinta (Science and Technology Index).

http://sinta2.ristekdikti.go.id/journals/detail?id=2963, diakses tanggal 22 Juli 2019.

Tupan \& Rahayu, R. N. (2018). Distribusi dan pola kepengarangan artikel pada Majalah Ilmiah Biologi Biosfera: 2010-2017. Khizanah al-Hikmah : Jurnal Ilmu Perpustakaan, Informasi, dan Kearsipan. 6(2), 132-140. DOI: https://doi.org/10.24252/kah.v6i2a5.

Wulan, Sri. (2017) Pola Kepenulisan dan Kolaborasi Penelitian Pada Jurnal Tseubia. Jurnal Baca, 38(2). 157-165. DOI: 10.14203/j.baca.v38i2.331. 
Bibliotech : Jurnal Ilmu Perpustakaan dan Informasi, 4 (1) 2019 